\title{
Model of A Practice-Oriented Educational Program
}

\author{
Maxim Sergeevich Logachev ${ }^{1 *}$, Olga Victorovna Semenova ${ }^{2}$, and Irina Viktorovna \\ Kulibaba $^{1}$ \\ ${ }^{1}$ Moscow Polytechnic University, Department of Infocognitive Technologies, Moscow, Russia \\ ${ }^{2}$ State Budget Professional Educational Institution of Moscow "College of Modern Technologies \\ named after the Hero of the Soviet Union M.F. Panov", Moscow, Russia
}

\begin{abstract}
One of the main educational problems in the Russian Federation in the past ten years is to organise a practice-oriented approach. This article substantiates this problem and provides possible ways to solve it. To establish important elements of the educational program to prepare highly qualified specialists, a model of practice-oriented educational programs is developed. It represents the educational process as a set of professional objectives for professional activities development. At the same time, a strong link is established between several academic disciplines represented by interdisciplinary courses. The professional task model is described in details to form an unambiguous understanding of the algorithm of actions performed, methods and tools used, potential risks and the final result. The results obtained can be used to unify the legal documentation that accompanies the educational process, and to compile practice-oriented educational courses or study guides.
\end{abstract}

\section{Introduction}

Practical experience shows that the main disadvantage of training is the fragmentary knowledge of students $[1,2,3,4]$. Weak inter-subject connections do not give an idea of the speciality (or profession) as a whole. The result is the absence of a complete system of knowledge, skills and abilities necessary for a future specialist $[5,6]$. The knowledge obtained in one academic discipline is poorly used in the study of other disciplines or is not used at all. The solution to this problem is practice-oriented educational programs, which gained their relevance after determining the TOP-50 most promising and popular professions, the introduction of the professional standards and World Skills standards [7].

The main and common element of these documents is a professional activity. Therefore, all educational programs should be designed in such a way as to master professional activities during training $[8,9]$.

Thus, the research purpose is to provide training of a specialist with full use of practiceoriented training tools. This requires developing a model of a practice-oriented educational program taking into account the requirements of the modern labour market, adapting

\footnotetext{
*Corresponding author: logachevmaxim@gmail.com
} 
educational programs to the requirements of the professional community and professional standards, and developing criteria for the quality of the educational program.

\section{Methods}

Using the structural analysis method, professional activity can be represented as a sequence of interrelated elements $[10,11,12]$ :

- speciality (profession or professional activity type for secondary vocational education);

- generalised labour functions;

- labour function;

- labour actions.

A survey of specialists who carry out self-examination and licensing procedures of educational organisations revealed that the labour functions include professional tasks that are solved by a specialist within their competence [13]. The set of professional tasks determines the content of professional activity $[14,15]$. For the success of such tasks, the solution algorithm must be clearly defined.

To create a practice-oriented educational program, the following methods should be followed $[16,17]$ :

1. The purpose of the program is to develop professional competencies.

2. Didactic functions include informational and instructive ones that can form the possibility of implementing professional activities. In this case, theoretical knowledge should be applied to ensure the implementation of professional tasks.

3. The structure of training tools should include interrelated components that allow for the implementation of algorithms for solving professional tasks, but also ways to control them.

4. The structural elements should include a set of interdisciplinary courses represented by a professional module.

5. The teacher organises the independent work of students, in other words, the subjectsubjective nature of training realised.

6 . The student must independently determine the need for theoretical knowledge for the successful performance of professional activities.

7. The result of training is the formation of professional competencies.

\section{Results}

If the requirements are met, the content of a practice-oriented educational program should consist of the following sections $[18,17]$ :

1. A target block that includes learning goals and objectives.

2. Objects of study that consists of describing the practices of solving professional tasks by highly qualified employees in real production conditions, requirements of professional (corporate) standards, requirements of the labour market and the expert community.

3. Organisational and content block that includes algorithms for solving and risks of erroneous solutions to professional tasks, knowledge and skills for the formation of each professional competence, requirements of the educational standard, the composition of the material and technical base and human resources of the educational organisation that support the educational process.

4. Evaluation and performance block, which defines criteria for evaluating the quality of professional competence formation.

Structural analysis of professional activities allows one to make a unified description of professional activities for each professional competence. This structural unit is a professional 
task. For example, a technical writer must be able to solve the following professional tasks for the competence "using modern software for solving professional tasks": study technical documentation, compile a user's guide, etc. [19] Each professional task has a specific result, and specific tools or methods are used to solve it. To get a specific result within a professional task, one needs to perform several manipulations (steps). The description of this step can be presented as an answer to the question "what to do". The step must be accurately named and strictly comply with all rules and regulations.

\section{Discussion}

Creating an algorithm for solving a professional problem, the step and the result of its execution should be differentiated. As practice shows, many teachers (or masters of industrial training) skip the description of simple manipulations (steps) and start solving a professional task with the result of its implementation. Thus, the student does not understand the sequence of actions that allow solving a professional problem [10, 17].

Each step must be performed consciously, and the student must imagine the result. It is impossible to form professional competencies in isolation from the real conditions in which future specialists will carry out their professional activities. Practice-oriented educational programs should form the students ' belief that the lack of knowledge or detailed understanding of the algorithm for performing a professional task makes it difficult or impossible to perform a specific professional reception. Thus, the successful implementation of professional activities is impossible in the absence of constant theoretical knowledge. The student must determine the sources of information independently since he must understand the responsibility for the accuracy of the information received [11]. Therefore, one should be responsible for the wrong decision themself. This approach to obtaining a professional task makes it possible to show the cause-and-effect relationships that exist within the speciality or profession.

\section{Conclusion}

The introduction of practice-oriented educational programs in the educational process, created according to the methodology presented in the article, creates conditions for modernising the approach to learning. Conditions are being created to encourage independent, network-based, combined forms of learning, training, and professional competencies. The content takes into account the objective factor of changing the main customer and consumer of educational organisations graduates: from the state to a variety of different scale enterprises, firms or companies since they are the ones who make requirements for the content, timing and methods of assessing the level of future specialists training.

Based on the presented models, the educational process is based on solving professional tasks, choosing appropriate forms, methods and means of training. This made it possible to develop some practice-oriented educational programs, textbooks, monographs and an information system that has a certificate of state registration.

\section{References}

1. M.G. Sergeeva, Kafedra: psikhologo-pedagogicheskiy zhurnal 1, 3-9 (2012)

2. M.S. Tigina, Vestnik MGUP imeni Ivana Fedorova 2, 310-314 (2015)

3. E. Bukhteeva, O. Kalney, S. Shishov, R. Rabadanova, I. Polozhentseva, Amazonia Investiga 8(20), 575-581 (2019) 
4. G.J. Hwang, C.C. Tsai, S.J.H. Yang, Educational Technology \& Society 11(2), 81-91 (2008)

5. M. Chan, International Journal of Educational Research 101, (2020)

6. S.S.Jaggars, D. Xu, Computers \& Education 95, 270-284 (2016)

7. S. Pivneva, N Vitkovskaya, Y.S. Sizova, E.N. Gorlacheva, Revista Inclusiones 7, 400413, (2020)

8. M.S. Logachev, G.S. Zhukova, Revista Inclusiones 7, 263-274 (2020)

9. M. Alashwal, Higher Education Research 5(1), 31-36 (2020)

10. M.S. Logachev, G.V. Tkacheva, Yu.N. Samarin, The educational program as a tool of the quality management system of vocational education: monograph (Infra-M, Moscow, 2019)

11. G.V. Tkacheva, Modeling the practice-oriented content of textbooks for vocational education: diss. ... cand. ped sciences (Moscow, 2012)

12. Y.E. Serebryanskiy, S.A. Bobinkin, O.Y. Dembitckaia, L.B. Kotova, Revista Inclusiones 7, 49-61 (2020)

13. M.S. Logachev, The structure, methodology and functioning algorithms of the monitoring system of quality management of educational programs: diss. ... cand. tech. Sciences (State radio engineering un-ty, Ryazan, 2017)

14. A. Kupchik, T. Monahan, British Journal of sociology of education 27(5), 617-631 (2006)

15. D.W. White, Florida Association of Teacher Educators Journal 14(1), 1-9 (2014)

16. M.S. Logachev, Yu.N. Samarin, M.S. Tigina, Automated systems for managing the quality of the educational process: monograph (MGUP named after Ivan Fedorov, Moscow, 2016)

17. G.V. Tkacheva, Professionalnoye obrazovaniye i obshchestvo 2(14), 84-87 (2015)

18. G.V. Tkacheva, Modeling the practice-oriented content of textbooks for vocational education: diss. ... cand. ped sciences (Moscow, 2012)

19. M.S. Logachev, O.V. Semenova, Information systems and programming. Technical writer. Graduation work: textbook. (Infra-M, Moscow, 2020) 